\title{
Cytochrome b gene based population study of Tenualosa ilisha (Hamilton) in the Brahmaputra river system of India
}

\author{
Rita Choudhury ${ }^{*}$, Puranjit Das ${ }^{2}$ \\ ${ }^{\mathbf{1}}$ Department of Zoology, Tihu College, Tihu, Nalbari-781371, Assam, India \\ ${ }^{2}$ Department of Zoology, Bhattadev University, Bajali, Pathsala-781325, Assam, India
}

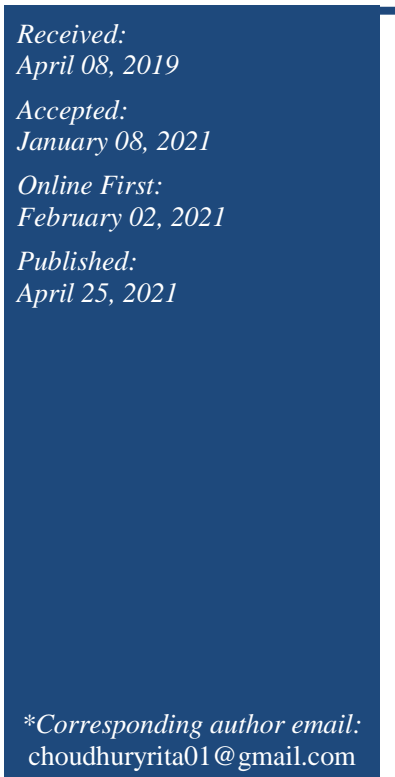

\begin{abstract}
Tenualosa ilisha, an anadromous fish, inhabited in the lower region of the estuaries and the foreshore areas migrating to river for spawning. The Hilsa population entered the Brahmaputra River system from Bay of Bengal. Various studies have shown the Hilsa population differs significantly from one another found in different rivers. In the present communication attempt has been made to investigate population of Hilsa shad in the Brahmaputra River using cytochrome b gene. Analysis of $425 \mathrm{bp}$ of Cytochrome b gene fragment revealed 4 haplotypes with two clusters in dendogram. Existence of three polymorphic sites in the haplotypes sequences obtained from two groups of Hilsa shad showed low genetic differentiation in the Brahmaputra River.
\end{abstract}

Keywords: Cytochrome b gene, Brahmaputra river, Tenualosa ilisha

\section{How to cite this:}

Choudhury R and Das P, 2021. Cytochrome b gene based population study of Tenualosa ilisha (Hamilton) in the Brahmaputra river system of India. Asian J. Agric. Biol. 2021(2): 201901033. DOI: https://doi.org/10.35495/ajab.2019.01.033

This is an Open Access article distributed under the terms of the Creative Commons Attribution 3.0 License. (https://creativecommons.org/licenses/by/3.0), which permits unrestricted use, distribution, and reproduction in any medium, provided the original work is properly cited.

\section{Introduction}

Hilsa shad, Tenualosa ilisha (Hamilton) is a popular fish found in India, Bangladesh, Pakistan, Myanmar, Indonesia, Sumatra, Kuwait, Iraq and Iran. The fish lives in the sea, but during breeding period they migrate to freshwater river. Hilsa fishing supports livelihood in Bangladesh and India, and to maintain sustainable Hilsa production, control of wanton killing of the breeding population is needed (Sunny et al., 2019). In India they migrate to the Brahmaputra and Ganga River system for spawning (Pillay and Rosa, 1963) and due to intense fishing and exploitation of brood fish during their upstream breeding migration its number is declining (Bhaumik, 2017). In Brahmaputra River Hilsa fishing is mainly done during the monsoon season, but during the later part of winter also, the mature fish come to river for spawning. The breeding season of Hilsa fish is mainly from May to August with a shorter season from January to February and sometimes it stretches into March. Different studies on population of Hilsa have been done by various authors encompassing morphometric and genetic aspects and found contradictory results. The Hilsa population was recognized as three different ecotypes by Majumdar (1939), three stocks by Pillay et al. (1963) and existence of different morphotypes by Ghosh et al, (1968). The molecular studies based on allozyme markers by Dhale et al. (1997) revealed genetic differences of Hilsa shad population between freshwater and brackish waters in Bangladesh, but similar studies by Lal et al. (2004) report the existence of a single panmictic population in India sampled from five rivers including Brahmaputra. Differences in 
Hilsa population in freshwater and brackish waters in Bangladesh were reported by Hussain et al. (1998) while working with RAPD marker. Salini et al. (2004) reported presence of genetically distinct Hilsa population in Bangladesh, Kuwait and Indonesia. The genetic study conducted by Rahman and Naevdal (2000) differentiated the marine group from freshwater and estuarine localities of the Hilsa population in Bangladesh. Similarly, Behera et al. (2015) found five haplotypes of in the Hilsa population in Bhagirathi and Tapti River by cytochrome b gene analysis. Verma et al. (2016) reported the presence of genetic differentiation among the Hilsa populations with high haplotype diversity in the Arabian Sea and Bay of Bengal from the sequencing of mitochondrial control region. In another study, SNP (single nucleotide polymorphism) analysis showed the presence of three genetically diverged local populations in different environmental habitats (Asaduzzaman et al., 2019; 2020). The ecology and adaptations of Hilsa were studied through genomic data by Mohindra et al. (2019) to know the adaptation mechanisms in different salinity levels during migration.

The present study of Hilsa population has aimed to find out any genetic variability in the Brahmaputra River system because the past studies unable to describe the population genetic structure. Therefore, partial sequencing of cytochrome $b$ gene of mitochondrial genome was done to find out the presence of genetically distinct Hilsa population in Brahmaputra River as it has been regarded as an important tool of genetic variability studies and analyzing the population structure and phylogenetic studies in fish and other animal species (Irwin et al., 1991; Li et al., 2009; He et al., 2011; Behera et al., 2015).

\section{Material and Methods}

\section{Sample collection}

A total of 80 samples of $T$. ilisha of varying size and weight were collected during the spawning period from different landing sites of the Brahmaputra River system in Dhubri and Goalpara district of Assam during the period of July 2017 to November 2017. From Goalpara district 27 (GH001- GH027) samples collected from four different locations, namely Madartary ghat, Krishnai, Joleswar ghat and fish Market of Goalpara town; and 53 (DH001- DH053) samples were collected from Netai Dhubuni Ghat, Dhubri New ghat, Jogomaya Ghat and Dhubri fish Market of Dhubri town. After taking weight and length of each fish, tissue samples of Hilsa were dissected out immediately and immersed in pure grade of ethanol in the sample bottle. After transporting to laboratory the vials were kept at $-80^{\circ}$ Celsius until DNA extraction.

\section{DNA extraction}

Total genomic DNA was isolated from muscle tissue by QIAGEN-DNeasy Blood and Tissue kit by manufacturer protocol. For each sample approximately $20 \mathrm{mg}$ of tissues was cut into small pieces and genomic DNA was extracted by proteinase $\mathrm{K}$ digestion. The extracted DNA was stored at $-20^{\circ} \mathrm{C}$ for PCR amplification. The extraction of DNA was followed by PCR amplification.

\section{Primers}

The partial cytochrome $b$ gene sequences of mitochondrial DNA were isolated via PCR. The primers used in the reaction was taken from Irwin et al. (1991) and the primers were L14724 (5'CGAAGCTTGATATGAAAAACCATCGTTG-3') and H15149 (5'AAACTGCAGCCCCTCGAATGATATTTGTCCTC A-3').

\section{PCR amplification}

The PCR reaction was done in $15 \mu 1$ reaction containing purified water $3.75 \mu \mathrm{l}$, taq buffer $1.5 \mu \mathrm{l}, \mathrm{MgCl}_{2} 1.5 \mu \mathrm{l}$, dNTPs $1.5 \mu 1$, primers $1.5 \mu 1$, BSA $1.5 \mu 1$, taq DNA polymerase enzyme $0.75 \mu 1$ and $3 \mu 1$ of extracted DNA. The PCR cycling profile was initial denaturation at $94^{\circ} \mathrm{C}$ for 5 minutes followed by 35 cycles comprising subsequent denaturation at $94^{\circ} \mathrm{C}$ for $30 \mathrm{sec}$, annealing at $53.4^{\circ} \mathrm{C}$ for $30 \mathrm{sec}$, extension at $72^{\circ} \mathrm{C}$ for $50 \mathrm{sec}$, incubation at $72^{\circ} \mathrm{C}$ for 10 minutes and finally at $4^{\circ} \mathrm{C}$ forever. 76 samples result positive PCR amplification. The amplified PCR products were then resolved on $2 \%$ agarose gel in 1XTBE buffer containing $2 \mu \mathrm{l}$ of ethidium bromide. After electrophoresis the PCR products were purified by adding $1 \mu 1$ of Exo-SAP (Exonuclease-I and Shrimp Alkaline Phosphatase in buffer) per $10 \mu l$ reaction and set in PCR machine as $37^{\circ} \mathrm{C}$ for 20 minutes, $80^{\circ} \mathrm{C}$ for 15 minutes and finally at $4^{\circ} \mathrm{C}$. After this, the purified PCR products were sequenced in the ABI Prism BigDye Terminator Cycle Sequencing kit (Applied Biosystems). 


\section{Data analysis}

Amplified cytochrome b regions were sequenced in both forward and reversed directions to check the validity of nitrogenous bases. Alignment of sequences was done automatically using CLUSTALW program (Thompson et al., 1994), inbuilt in the genetic analysis package MEGA 7 (Kumar et al., 2016). The sequences were checked with the Chromas software (Technelysium, Australia) and then visually refined. The sequenced data were analyzed with the help of BLAST (www.ncbi.nlm.nih.gov.) for homology search. Sequence variation sites, nucleotide diversity and haplotype diversity within population were estimated using DnaSP v5 (Librado and Rozas, 2009). After finding of haplotypes, a Neighbor-joining tree was constructed for all haplotypes with the Gadusia chapra sequence (Accession number: AP011603) as an outgroup based on the Kimura's 2 parameter model using MEGA 7.0. By applying this same model genetic distance among the haplotypes were also calculated. To assess confidence in the branching of dendrogram bootstrap analysis (1000 data sets) was performed. For a visualization of the relationship among the haplotypes Median-joining (MJ) network from all Hilsa sequences was constructed using the Network 5.0 (Bandelt et al., 1999). To explain the genetic structure of the Hilsa population collected from Goalpara and Dhubri, the allele frequencies (Fst) and AMOVA analysis were done in Arlequin 3.5 (Excoffier and Lischer, 2010).

\section{Results}

The Nucleotide positions of the sequenced segment of DNA were assigned from $14348^{\text {th }}$ to $14773^{\text {th }}$ position according to the complete mitochondrial genome reference sequence of the GenBank accession no. AP011610 and NCBI Blast result. From the sequenced cytochrome $\mathrm{b}$ region of $T$. ilisha samples, four haplotypes were obtained. The haplotype sequences have three variable (polymorphic) sites; out of these two are singleton variable sites and one parsimony informative sites. The average nucleotide diversity of the haplotypes is $0.002496 \pm 0.001852$ and the average nucleotide composition of all haplotype sequences are 25.92\% Adenine, 27.53\% Thymine, $17.49 \%$ Guanine and $29.06 \%$ Cytosine. The mean number of pairwise difference is $1.060702 \pm 0.710370$. The haplotype diversity is 0.533 and the average number of nucleotide differences is 1.667 , indicating the low genetic diversity in Hilsa population in the Brahmaputra River. The similarity or percentages of the identity of haplotypes obtained were compared (Table 1) with some of the Genbank sequences of the respective part of the DNA sequence. This implies that the haplotypes H_1 and H_4 has 100\% similarity with few Genbank sequences. The Neighbor-Joining tree (Fig.1) has shown medium bootstrap values among the 4 haplotypes where Gadusia chapra was used as an outgroup.

Table-1. The percentage of similarities/identities of the 4 haplotypes with few GenBank sequences

\begin{tabular}{|c|c|c|c|c|}
\hline $\begin{array}{c}\text { GenBank } \\
\text { Acc. No. }\end{array}$ & H_1 & H_2 & H_3 & H_4 \\
\hline AP011611 & $\begin{array}{c}426 / 426 \\
(100 \%)\end{array}$ & $\begin{array}{c}425 / 426 \\
(99 \%)\end{array}$ & $\begin{array}{c}422 / 426 \\
(99 \%)\end{array}$ & $\begin{array}{c}425 / 426 \\
(99 \%)\end{array}$ \\
\hline EU552622 & $\begin{array}{c}403 / 403 \\
(100 \%)\end{array}$ & $\begin{array}{c}402 / 403 \\
(99 \%)\end{array}$ & $\begin{array}{c}400 / 403 \\
(99 \%)\end{array}$ & $\begin{array}{c}402 / 403 \\
(99 \%)\end{array}$ \\
\hline JX213630 & $\begin{array}{c}307 / 307 \\
(100 \%)\end{array}$ & $\begin{array}{c}306 / 307 \\
(99 \%)\end{array}$ & $\begin{array}{c}304 / 305 \\
(99 \%)\end{array}$ & $\begin{array}{c}304 / 304 \\
(100 \%)\end{array}$ \\
\hline JX213631 & $\begin{array}{c}306 / 307 \\
(99 \%)\end{array}$ & $\begin{array}{c}305 / 307 \\
(99 \%)\end{array}$ & $\begin{array}{c}303 / 305 \\
(99 \%)\end{array}$ & $\begin{array}{c}303 / 304 \\
(99 \%)\end{array}$ \\
\hline
\end{tabular}

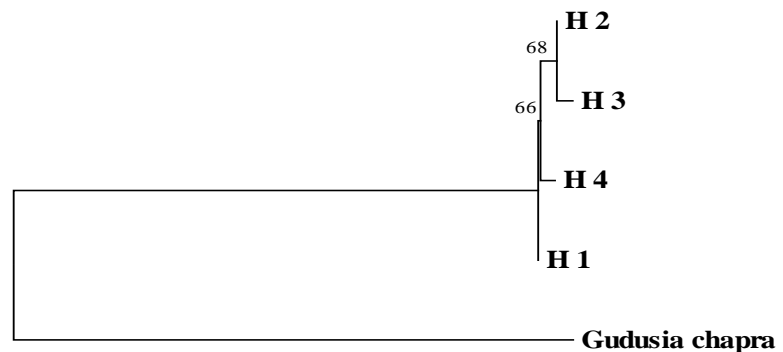

$$
\text { } 0.02
$$

Figure-1. Neighbor-Joining tree depicting relationships among the 4 haplotypes obtained from 76 sequences of Hilsa samples from Brahmaputra River with an outgroup Gadusia chapra (Acc. No. AP011603). The bootstrap values are shown next to the branches.

All the four haplotypes form two clades. Clades A composed of haplotype H_1 with H_4 and clade B comprises haplotype $\mathrm{H} \_2$ with $\mathrm{H} \_3$. As depicted in the phylogenetic tree the interclade differences between the Hilsa populations of Brahmaputra River is low. Medium bootstrap value was observed in the tree signifies the differentiation. Pair-wise genetic distance values between the haplotypes are shown in table 2 where more genetic divergence was found between 
haplotype H_3 and haplotype H_4. The Median joining network (Fig.2) showed the positions of haplotypes. The MJ network showed the interrelation of haplotypes and their mutation sites. A single mutation site was observed by the network for all four haplotypes. The four haplotypes obtained in this study comprising of different frequencies (Fig. 3). At both the locations similar haplotypes were obtained except the H_3 which was only recorded in Dhubri. The haplotype 4 (H_4) comprises the largest number of sequences $(46.05 \%)$ and percentage of occurrences of other three haplotypes namely $\mathrm{H} \_1, \mathrm{H} \_2$ and $\mathrm{H} \_3$ are $19.74 \%, 28.95 \%$ and $5.26 \%$ respectively. While conducting genetic structure analysis of Hilsa population, the Fst value (0.03604) showed that there is a little difference between the groups (Wright, 1965). In the AMOVA analyses the genetic variation within the population was found $68.94 \%$, whereas between the groups was $3.70 \%$. The mean pairwise difference of Dhubri and Goalpara groups are 0.6556 and 0.6400 respectively.

Table-2. Pair-wise genetic distance values among the haplotypes.

\begin{tabular}{|c|c|c|c|}
\hline & H_1 & H_2 & H_3 \\
\hline H_1 & & & \\
\hline H_2 & 0.002 & & \\
\hline H_3 & 0.005 & 0.002 & \\
\hline H_4 & 0.002 & 0.005 & 0.007 \\
\hline
\end{tabular}

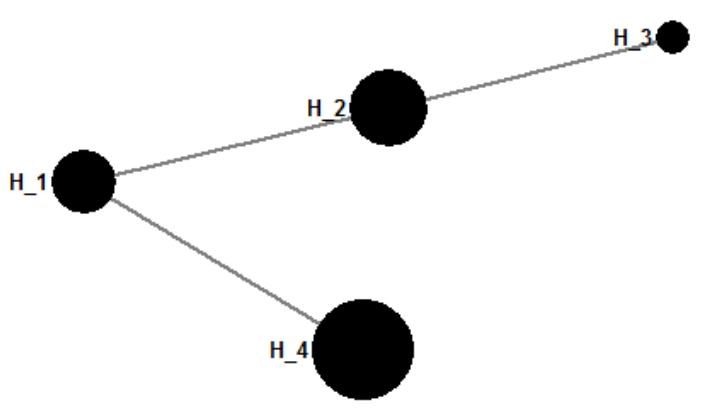

Figure-2. Median joining network constructed from $\mathbf{7 6}$ cytochrome b sequences of Tenualosa ilisha. Each circle represents one haplotype and the circle size is related to the frequency of haplotypes.

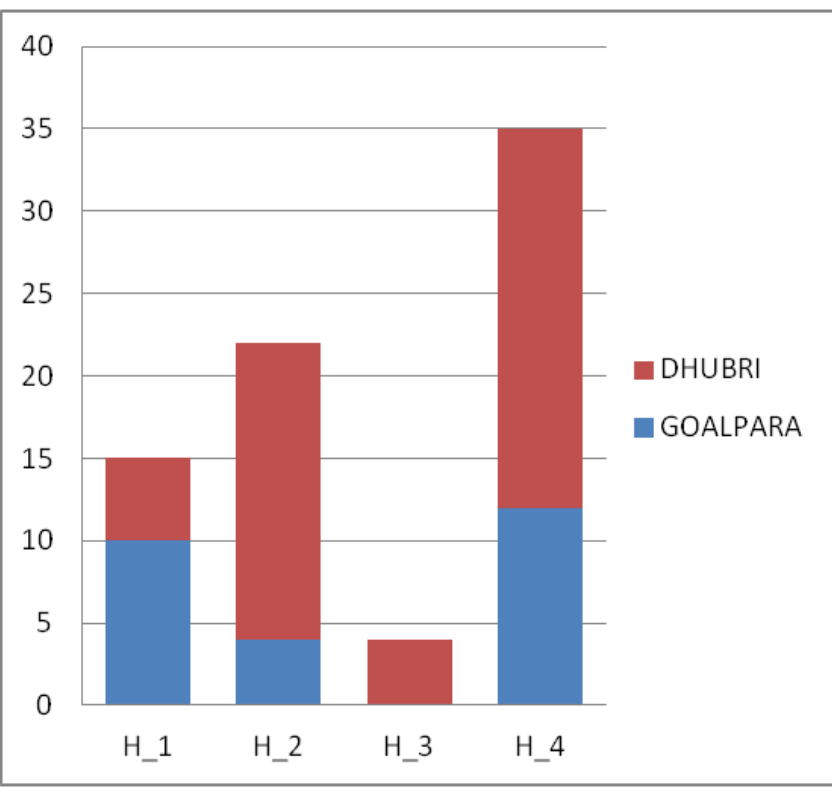

Figure-3. Distributions and frequencies of occurrences of 4 haplotypes of Hilsa in two collection sites $(\mathrm{N}=76)$

\section{Discussion}

A detailed knowledge of the genetic makeup is of primary importance for management as well as survival of a species. The future of a population is dependent upon its genetic diversity. The genetically less diverged population utilized limited available habitat, thereby create competition among themselves (Johnson et al., 2016). The present analysis of the 76 cytochrome $\mathrm{b}$ sequences comprising two groups showed that the there exists genetic variation with one transition and two transversions in the Hilsa population in the Brahmaputra River. The population differentiation between the two groups was less significant, although $\mathrm{H}_{-} 3$ was only found in one group. A number of similar studies suggested the existence of different races of Hilsa shad in India and Bangladesh. Brahmane et al. (2013), studied cytochrome $b$ gene of Hilsa population from Ganga and Hooghly Rivers and found low genetic diversity with single population. In contrast Behera et al. (2015) found five cytochrome $b$ gene haplotypes of Hilsa in Bhagirathi and Tapti River where the differentiation of population was established in a single nucleotide substitution in the $307 \mathrm{bp}$ length of cytochrome $\mathrm{b}$ gene. A genetically variable population of Hilsa in Bangladesh was also obtained by Rahman and Naevdal (2000) using Randomly Amplified Polymorphic DNA (RAPD) markers; Ahmed et al. 
(2004) while working on RFLP analysis of the mtDNA D-loop region and Mazumder and Alam (2009) by PCR-RFLP analysis of the mtDNA D-loop region. Verma et al. (2016) while working on the mitochondrial control region found broad structuring of Hilsa population between the Arabian Sea and Bay of Bengal but did not detect structure among riverine populations. However the recent SNP study based on NextRAD sequencing suggested that existence of local adaptive riverine populations called genetically structured ecotypes in differing environmental habitats (Asaduzzaman et al., 2019). In addition to this, two genetically structured clusters, one from marine and estuarine and other from riverine collection sites were described in where the riverine population was further subdivided into turbid freshwater and the clear freshwater ecotypes (Asaduzzaman et al., 2020). In the current study, 4 haplotypes of Hilsa were obtained, but the differentiation between haplotypesa is nominal. However, it is also important to note that a $425 \mathrm{bp}$ nucleotide study is not sufficiently reasonable to make a conclusion over a species. But it can be ascertained that there exists a genetically variable Hilsa population in the River Brahmaputra. Owing to this low genetic differentiation of the Hilsa population, the haplotypes obtained in this study cannot be regarded as a separate race or sub population and thereby it is difficult to demonstrate the Hilsa population as distinct one and separate from each other Rivers. The low differentiation observed might be due to inbreeding population structure and other evolutionary forces such as migration, selection, genetic drift and geographic barriers. Therefore, it can be said that Hilsa population of Brahmaputra River is genetically polymorphic though it did not reveal much genetic variation in the population. A combined study of physical, ecological, morphometric, and genetic study with more molecular marker may solve the question of existence of ecotypes and riverine population differentiation of Hilsa shad.

\section{Conclusion}

The present study has revealed significant information on the genetic structure of Hilsa population in Brahmaputra River and can be concluded that a genetically variable Hilsa population is available in the Brahmaputra River.

\section{Acknowledgment}

The authors are grateful to Prof. U.C. Goswami (now late) of Gauhati University, Assam for his conceptualization, design, kind support and advice of this study.

\section{Disclaimer: None.}

Conflict of Interest: None.

Source of Funding: None.

\section{References}

Ahmed ASI, Islam MS, Azam MS, Rahman MM and Alam S, 2004. RFLP analysis of the mtDNA D-loop region in Hilsa shad (Tenualosa ilisha) population from Bangladesh. Indian J. Fish. 51(1): 25-31.

Asaduzzaman M, Wahab MA, Rahman MJ, Nahiduzzaman M, Dickson MW, Igarashi Y, Asakawa S and Wong LL, 2019. Fine-scale population structure and ecotypes of anadromous Hilsa shad (Tenualosa ilisha) across complex aquatic ecosystems revealed by NextRAD genotyping. Sci. Rep. 9:16050.

Asaduzzaman M, Igarashi Y, Wahab MA, Nahiduzzaman M, Rahman MJ, Phillips MJ, Huang S, Asakawa S, Rahman MM and Wong LL, 2020. Population Genomics of an Anadromous Hilsa Shad Tenualosa ilisha Species across Its Diverse Migratory Habitats: Discrimination by Fine-Scale Local Adaptation. Genes. 11: 46.

Bandelt HJ, Forster P and Rohl A, 1999. Median-joining networks for inferring intraspecific phylogenies. Mol. Biol. Evol. 16(1):37-48.

Behera BK, Singh NS, Paria P, Sahoo AK, Panda D, Meena DK, Das P, Pakrashi S, Biswas DK and Sharma AP, 2015. Population genetic structure of Indian shad, Tenualosa ilisha inferred from variation in mitochondrial DNA sequences. J. Environ. Biol. 36(5):1193-7.

Bhaumik U, 2017. Fisheries of Indian Shad (Tenualosa ilisha) in the Hooghly-Bhagirathi stretch of the Ganga River system, Aquatic Ecosystem Health \& Management, 20:1-2, 130-139.

Brahmane MP, Kundu SN, Das MK and Sharma AP, 2013. Low genetic diversity and absence of population differentiation of Hilsa (Tenualosa ilisha) revealed by mitochondrial DNA cytochrome $b$ region in Ganga and Hooghly rivers. Afr. J. Biotechnol. 12(22): 3383-3389.

Dhale G, Rahman M and Eriksen AG, 1997. RAPD fingerprinting used for discriminating among three 
populations of Hilsha shad (Tenualosa ilisha). Fish. Res. 32:263-269.

Excoffier L and Lischer HEL, 2010. Arlequin suite ver 3.5: A new series of programs to perform population genetics analyses under Linux and Windows. Mol. Ecol. Resour. 10: 564-567.

Ghosh AN, Bhatacharya RK and Rao KV, 1968. On the identification of subpopulation of Hilsa Ham. in the Gangetic system, with a note on their distribution. Proc. Nat. Inst. Sci. India. 34B: 44-59.

He A, Luo Y, Yang H, Liu L, Li S and Wang C, 2011. Complete mitochondrial DNA sequences of the Nile tilapia (Oreochromis niloticus) and blue tilapia (Oreochromis aureus): genome characterization and phylogeny applications. Mol. Biol. Rep. 38(3): 2815-2821.

Hussain MG, Salini JP, Islam MS and Mazid MA, 1998. Genetic structure of Hilsa shad populations: preliminary results using starch gel allozymes. Proceedings of BFRI/ ACIAR/CSIRO Workshop on Hilsa Fisheries Research in Bangladesh, 3-4 March 1998.

Irwin DM, Kocher TD and Wilson AC, 1991. Evolution of the cytochrome $b$ gene of mammals. J. Mol. Evol. 32:128-144.

Johnson DW, Freiwald J and Bernardi G, 2016. Genetic diversity affects the strength of population regulation in a marine fish. Ecol. 97(3):627-39.

Kumar S, Stecher G and Tamura K, 2016. MEGA7: molecular evolutionary genetics analysis version 7.0 for bigger datasets. Mol. Biol. Evol. 33: 1870-1874.

Lal KK, Kumar D, Srivastava SK, Mukherjee A, Mohindra V, Prakash S, Sinha M, and Ponniah AG, 2004. Genetic variation in Hilsa shad (Tenualosa ilisha) population in river Ganges, Indian J. Fish. 51(1): 33-42.

Librado P and Rozas J, 2009. DnaSP v5: A software for comprehensive analysis of DNA polymorphism data. Bioinformat. 25: 1451-1452.

Li GY, Wang XZ, Zhao YH, Zhang J, Zhang CG and He SP, 2009. Speciation and phylogeography of Opsariichthys bidens (Pisces: Cypriniformes: Cyprinidae) in China: analysis of the cytochrome $b$ gene of mtDNA from diverse populations. Zool. Stud. 48:569-583.

Majumdar CH, 1939. Culture of Hilsa. Mod. Rev. 66: 293-297.

Mazumder KK and Alam MS, 2009. High levels of genetic variability and differences in Hilsa shad, Tenualosa ilisha (Clupeidae, Clupeiformes) populations revealed by PCR-RFLP analysis of the mitochondrial DNA D-loop region. Genet. Mol. Biol. 32: 190-196.

Mohindra V, Dangi T, Chowdhury LM and Jena JK, 2019. Tissue specific alpha-2- Macroglobulin (A2M) splice isoform diversity in Hilsa shad, Tenualosa ilisha (Hamilton, 1822). PLoS ONE 14(7): $\mathrm{e} 0216144$. https://doi.org/10.1371/journal.pone.0216144.

Pillay TVR and Rosa Jr, 1963. Synopsis on Biological Data on Hilsa, Hilsa ilisha (Hamilton 1882). FAO Fish. Biol. Synopsis. 25(1): 1-6.

Pillay TVR, Pillay SR and Ghosh KK, 1963. A comparative study of the populations of Hilsa, Hilsa ilisha (Hamilton) in the Indian water. Proc. IndoPacif. Fish. Coun. 10: 62-104.

Rahman M and Naevdal G, 2000. Population genetic studies of Hilsa shad, Tenualosa ilisha (Hamilton), in Bangladesh waters: evidence for the existence of separate gene pools. Fish. Manage. Ecol. 7:401-411.

Salini JP, Milton DA, Rahman MJ and Hussain MG, 2004. Allozyme and morphological variation throughout the geographic range of the tropical shad, Hilsa Tenualosa ilisha. Fish. Res. 66: 53-69.

Sunny AR, Ahamed GS, Mithun MH, Islam MA, Das B, Rahman A, Rahman MT, Hasan MN and Chowdhury MA, 2019. Livelihood Status of The Hilsa (Tenualosa ilisha) Fishers: The Case of Coastal Fishing Community of The Padma River, Bangladesh. J. Coast. Zone Manage. 22:469.

Thompson JD, Higgins DG and Gibson TJ, 1994. CLUSTAL W: Improving the sensitivity of progressive multiple sequence alignment through sequence weighting, position-specific gap penalties and weight matrix choice. Nucleic Acids Res. 22: 4673-4680.

Verma R, Singh M and Kumar S, 2016. Unraveling the Limits of Mitochondrial Control Region to Estimate the Fine Scale Population Genetic Differentiation in Anadromous Fish Tenualosa ilisha. Scientifica. 2016. DOI: http://dx.doi.org/10.1155/2016/2035240

Wright S, 1965. The interpretation of population structure by F-statistics with special regard to systems of mating. Evol. 19(3):395-420.

\section{Contribution of Authors}

Choudhury R: Conducted DNA extraction and PCR amplification and wrote the article

Das P: Collected samples, conducted the genetic analysis and revised manuscript 